\title{
Article \\ The Interplay between Tectonic Activity, Climate and Sea-Level Change in the Suriname River Valley, Tropical South America
}

\author{
Kathleen S. Gersie ${ }^{1, *}$, Ronald T. Van Balen ${ }^{2,3}$ and Salomon B. Kroonenberg ${ }^{1,4}$ \\ 1 Geosciences Department, Faculty of Technological Sciences, Anton de Kom University of Suriname, \\ Leysweg 86, Paramaribo, Suriname; S.B.Kroonenberg@tudelft.nl \\ 2 Department of Earth Sciences, Vrije Universiteit Amsterdam, De Boelelaan 1085, \\ 1081 HV Amsterdam, The Netherlands; R.t.van.balen@vu.nl \\ 3 TNO-Geological Survey of the Netherlands, Princetonlaan 6, 3584 CB Utrecht, The Netherlands \\ 4 Civil Engineering and Geosciences, Delft University of Technology, Stevinweg 1, \\ 2628 CN Delft, The Netherlands \\ * Correspondence: Kathleen.gersie@uvs.edu; Tel.: +597-8578054
}

Citation: Gersie, K.S.; Van Balen, R.T.; Kroonenberg, S.B. The Interplay between Tectonic Activity, Climate and Sea-Level Change in the Suriname River Valley, Tropical South America. Quaternary 2021, 4, 11. https://doi.org/10.3390/quat4020011

Academic Editors: David Bridgland, Xianyan Wang and Jef Vandenberghe

Received: 30 November 2020

Accepted: 9 March 2021

Published: 25 March 2021

Publisher's Note: MDPI stays neutral with regard to jurisdictional claims in published maps and institutional affiliations.

Copyright: (c) 2021 by the authors. Licensee MDPI, Basel, Switzerland. This article is an open access article distributed under the terms and conditions of the Creative Commons Attribution (CC BY) license (https:// creativecommons.org/licenses/by/ $4.0 /)$

\begin{abstract}
Suriname is part of the Guiana Shield, a cratonic area in northern South America. It is drained by several major rivers that are characterized by river terraces. The formation of terraces along the Suriname river is closely related to climatic changes during the Quaternary, due to the effects of climate on vegetation and precipitation changes. The terraces along the Suriname River valley show levels of 5, 15, and $20 \mathrm{~m}$ above the current mean water level. The reason behind the scarce terrace differentiation is the limited amount of long-term vertical incision. Therefore, each level along the Suriname River valley encompasses multiple climate cycles, which cannot be separated on morphological grounds. The limited incision reflects tectonic stability, which is typical for cratonic areas. Fieldwork along the river combined with topographic maps were used to determine and correlate the various terrace levels. While in the upper part of the river, climatically induced changes in vegetation cover and sediment delivery is dominant. In the lowermost reach, sea level change is especially important.
\end{abstract}

Keywords: fluvial terraces; tropical South America; craton; Northern Suriname

\section{Introduction}

Fluvial landscapes are an important part of the general geomorphological system. Among these, rivers in stable cratonic areas covered by rainforest are among the least studied ones. While they may show a large range of mean annual discharges and drainage basin areas, they are distinguished by unusually low sediment yields and sediment yield per square kilometer [1]. However, contrary to what these authors state, these rivers are not dominated by bedload but instead by a predominance of suspended load. This is due to the fact that the deeply weathered land surfaces hardly provide bedrock gravel but only their weathering products, e.g., sand, silt, and clay. This results in a lack of erosive power of the rivers, even at high discharges, so that when during incision hard bedrock is encountered, they are incapable of eroding them away due to the lack of bedload, and instead the channel splits itself up in several branches in order to avoid the obstacles. In this way, a very specific channel form develops, i.e., multibranch cataracts called raudales in Spanish South America such as in the Orinoco River, and well described by [2] for the Caroni River in Venezuela, cachoeiras in Brazil, and sulas in Suriname [3]. These channel forms resemble to some extent braided river channels but differ from them in the fact that they consist of rocky islands with fixed positions, instead of sand bars which change position during each flooding event. Even those outcrops in the river do not lead to the formation of bedload gravel as exfoliation sheets falling from them into the river, for instance, which usually disintegrate by weathering before being able to form solid clasts. 
Yet, like rivers from other environments, these rivers flowing in cratonic areas may exhibit river terraces with rounded gravel, suggesting different hydrological regimes and climatic environments in the past [4,5]. We present here a case study on the terraces of the Suriname River in the Guiana Shield in tropical South America, with a drainage basin wholly covered by tropical rainforest. It is known from palynological studies that the Guiana Shield has suffered periods of greater drought and lesser vegetation cover $[6,7]$. The study of terraces in this environment, however, is hampered by several factors, including low uplift rates, deep sediment weathering, and a scarcity of datable material.

Terraces are being recognized as an important source of evidence for Quaternary paleoenvironments [8] and, therefore, represent paleo-fluvial floodplains. Terrace formation in the lower reaches of rivers is driven by fluctuating sea level [9], whereas in areas remote from the marine influence, climate change produces a contrasting effect, with aggradation during glacial and incision during interglacial. However, the upstream influence of sea level fluctuation is likely to be limited because many rivers today flow in valleys that formerly extended over wide areas of continental shelf, but have been truncated by the Holocene marine transgression, which inundated and submerged their lower reaches [10]. Where the shelf is narrow, sea level fluctuation has given rise to terraces that can be traced for considerable distances inland, which is the case for example for the Susquehanna in North America [11] and other neighboring rivers in northern California [12].

The formation of terrace staircases is in most cases a response to regional uplift, which forces long-term incision [8,13-15]. The rivers in tropical Suriname have a maximum of about $20 \mathrm{~m}$ high, which is much less compared to what is commonly observed in high latitudes. Suriname is underlain by cratonic crust. In general, such crust is tectonically very stable and lacks a weak lower crustal layer, which would otherwise enable vertical motions by isostatic responses to loading [16]. Therefore, if this 20-m long term incision is caused by uplift, then this is in agreement with Suriname's cratonic crust.

According to [5], the formation of terraces along rivers in Suriname is closely related to climatic changes during the Quaternary due to the effects of climate on vegetation and precipitation changes. In his model, glacial alluvial sediments are deposited in the river valleys and valleys are widened during glacials. During interglacials, the rivers incise, leaving the former floodplain behind as a terrace in the landscape. However, the number of terraces in Suriname $(\sim 3)$ is much smaller than the number of climate cycles during the Pliocene and Quaternary. In addition, close to the coast, climate driven eustatic sea level fluctuations also should have an important control on river terrace formation. For example, when low stand base levels were lowered by up to $\sim 120 \mathrm{~m}$ and were submerged, $160 \mathrm{~km}$ Suriname shelf was exposed and incised by fluvial systems.

This study gives an overview of the Pleistocene terraces and the Holocene floodplain along the Suriname River valley, located in the central part of Suriname. Economically, this is Suriname's most important river, and it flows along the capital, Paramaribo. River terraces and floodplains are preferred sites for human settlement (villages) in the hinterland of Suriname. A detailed study would give more insight in the key controls (e.g., uplift, sea level fluctuation, climate changes) that are responsible for river terrace development along the Upper and Lower River valley parts. Literature studies, fieldwork, and laboratory analysis were used to determine the various characteristics of the terraces (e.g., height relative to mean water level, lithology). Our results are based on previous field work carried out in the 70s and 80s in the upstream parts and new mapping based on interpretations using historic land use maps in the midstream part, and a combination of Digital Elevation Model DEM and topographic maps analyses and field work in the downstream part. We provide, for the first time, full detailed maps of the distribution of terrace remnants of the whole river, and we show the terrace remnants in a longitudinal profile. Using these results, we discuss the formation mechanism and the relation to climate change. 


\section{Regional Settings}

\subsection{General}

Suriname is drained by seven rivers that are subdivided in three main groups based on the extent and shape of the drainage area (Figure 1). The first group consists of the border rivers Marowijne (East) and Courantyne (West), which have their sources in the border mountains with Brazil and drain almost $58 \%$ of the country. The second group has their origin in the high uplands in the middle of the country, and is represented by the Suriname and Coppename Rivers, which drain almost $24 \%$ of the country and debouch directly into the sea. The third group consists of the Commewijne, the Saramacca, and the Nickerie Rivers, that together drain approximately $16 \%$ of the country. The rivers of the last group bend westwards close to the coast to drain into the sea through the mouths of the second group, due to the westward migration of important mud banks along the coast $[17,18]$.

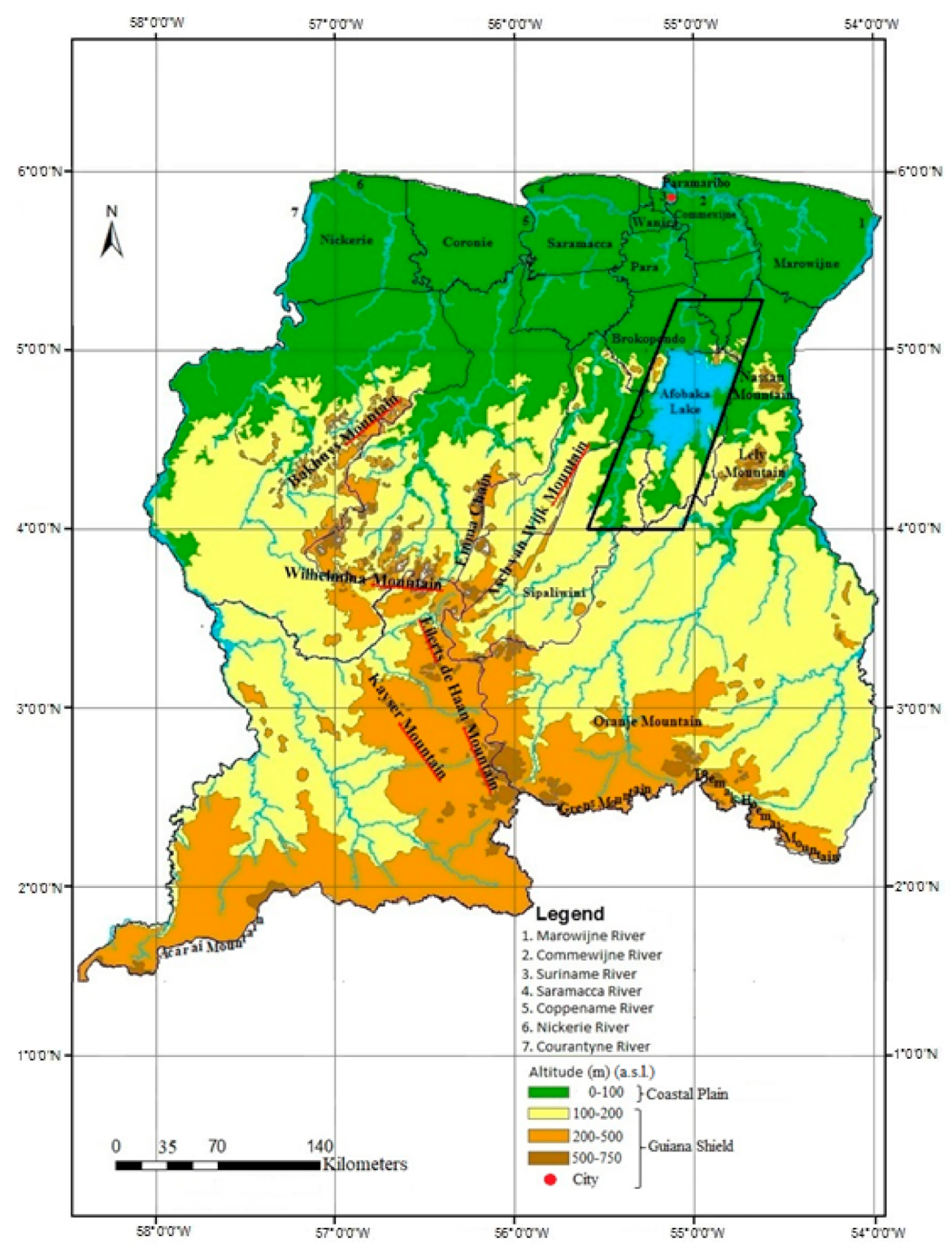

Figure 1. Simplified topographic map and hydrographic network of Suriname with its seven main rivers (Marowijne, Commewijne, Suriname, Saramacca, Coppename, Nickerie, and Courantyne Rivers) in the north. The frame indicates the location of the study area. 
The rivers run through two geologically different parts of the country, first through the hills and mountains of the cratonic Guiana Shield, while the estuary part runs through the Coastal Plain [18,19].

\subsection{Geological and Geomorphological Overview of the Study Area}

Suriname can be divided into a southern rainforest-covered interior, which represents almost $80 \%$ of the country's surface, and a northern coastal plain that makes up the rest of the country's surface area. The rainforest-covered interior, which forms part of the Guiana Shield, is underlain essentially by Precambrian igneous and metamorphic rocks, also called the basement (Figure 1 shows that the Guiana Shield roughly corresponds to the areas > $100 \mathrm{~m}$ ). Thick dolerite dykes with a $1782 \mathrm{Ma}$ age (Avanavero Dolerite) and narrow ones of Jurassic age (Apatoe Dolerite) intersect the basement of Suriname [20].

The morphology of the major part of the rain-forest covered basement consists of an endless mosaic of low hills with flat tops and steeply cut creek valleys. A distinction can be made into mountain tops up to $1280 \mathrm{~m}$ high, inselbergs at more than $700 \mathrm{~m}$ elevation, duricrust planation levels at more than $500 \mathrm{~m}$, and river terraces at levels of approximately $20 \mathrm{~m}, 15 \mathrm{~m}$, and $5 \mathrm{~m}$ above the mean water level. The terraces along the rivers are the only morphological units that are aligned with the present drainage pattern [21]. Structures in the bedrock (e.g., faults and fractures) control the drainage directions, as shown by the rectangular patterns of the larger rivers (Figure 1).

The coastal plain consists of the Savannah Belt, the Old Coastal Plain, and the Young Coastal Plain. The Savannah Belt is a gently sloping north-facing hilly landscape between 10 to $50 \mathrm{~m}$ above sea level. The Savannah Belt is underlain by the Pliocene Zanderij Formation, which consists of horizontally layered deposits of coarse sands with small amounts of loams and fine sands. The Zanderij deposits can reach a thickness of up to $20 \mathrm{~m}$. Gravel deposits, up to $2 \mathrm{~m}$ thick, are locally found at the base of this formation. The Zanderij Formation was deposited during dry climate conditions [22].

The Old Coastal Plain is situated 4 to $11 \mathrm{~m}$ above sea level and is a dissected Pleistocene marine terrace, consisting of numerous small plateaus, the so-called "schollenlandschap". This landscape has a variable width of $20 \mathrm{~km}$ in the east to $70 \mathrm{~km}$ in the west. Remarkable features are the Old Ridge Landscape, and the Old Clay Landscape that originated due to the westward transport of sediments along the coast under the influence of the Guiana Current. The Old Coastal Plain consists of sands and clays of the Coropina Formation, which can be subdivided into the lower clayey Para member and the upper sandy Lelydorp member. The Para member has been deposited around circa $700 \mathrm{ka}$, while the Lelydorp member is of Eemian age, which is approximately $120 \mathrm{ka}$ [22].

The Holocene Young Coastal Plain deposits are subdivided into the Mara Formation, which formed between 10-6 ka, and the Coronie Formation formed between around $6 \mathrm{ka}$ to the present. This younger part of the coastal plain is a flat clay-prone surface that is locally interrupted by east-west oriented sandy cheniers. These cheniers mark former coastlines and appear as single units or bundles [17].

The Suriname River valley has a total length of $480 \mathrm{~km}$ and has its sources in the highlands (Figure 1). Its catchment size is approximately $16,500 \mathrm{~km}^{2}$, and $84.8 \%$ of the total catchment area is located in the rainforest-covered interior of the Guiana Shield, 4.5\% in the Savanna Belt, and a $10.7 \%$ is in the Old and Young Coastal Plain [18,23]. The Afobaka Dam (1964) and Prof. Dr. W.J. van Blommestein Lake (also known as the Brokopondo or Afobaka Storage Lake) lie in the midstream part of the Suriname River valley. Downstream of the Afobaka Dam ( $\mathrm{km} \mathrm{194)} \mathrm{the} \mathrm{average} \mathrm{annual} \mathrm{discharge} \mathrm{of} \mathrm{the} \mathrm{river} \mathrm{is} 324 \mathrm{~m}^{3} / \mathrm{s}$. At the river mouth, the average annual discharge is estimated to be about $440 \mathrm{~m}^{3} / \mathrm{s}$, while the estimated sediment discharge is 0.25 million tons per year [19].

The river can only incise in saprolite or regolith because of the lack of abrading bedload [24]. A specific characteristic of all rivers in the basement area, including the Suriname River valley, is the presence of cataracts (sulas, in Surinamese). These are hard rock sills. At such locations the river's channel pattern resembles that of a braided river. 
However, in contrast to the gravel or sand banks in real braided rivers, the islands between the branches consist of hard rock $[3,25]$. The most downstream sulas in the Suriname river valley are the Brokopondo and Balling Sulas, just downstream of the Afobaka dam. They are situated at the northern edge of the basement, the Guiana Shield. They form semipermanent knickpoints in the river that they are supposed to be stable but are subject to slow erosion and have an important impact on river dynamics during climate-driven baselevel change and upstream changes in vegetation and sediment output (see Discussion).

\subsection{Climate and Environmental Conditions from the Pliocene to Holocene in Northern South America}

\subsubsection{Pliocene and Pleistocene}

The Miocene and Pliocene tectonics affect the Eastern Andes, fundamentally changing and the regional climate and the drainage patterns, which leads to the formation of the present-day Amazon and Orinoco river systems [26]. The Suriname River valley might have originated during the same time span. Climate conditions during the Pliocene seem to have been generally cooler than during the Miocene. Especially the final part of the Pliocene (between about 3 and 2.5 Ma BP) experienced a strong cooling [27-30].

Climatically, the Pliocene can be subdivided into a warm early Pliocene, a relatively warm Mid-Pliocene, and a relatively cool Late Pliocene [31]. Yet the average climate during the Pliocene appears to have been warmer than present day [32]. The pattern of temperature and precipitation change during the Pliocene was similar to weather and climate patterns observed during a modern El Niño event [33].

In general, very little is known about the Pleistocene climate in tropical South America before $0.5 \mathrm{Ma}$ [34]. The best data available refer only to the Last Glacial and the Holocene. We therefore restrict the discussion to that period, taking it as an analogue for previous Pleistocene climate cycles. During the Middle Pleniglacial (ca. 60-26 ka), most or all of warm and cold tropical South America had a considerably cooler climate and relatively high precipitation values. It became markedly drier between ca. 21 and 14 ka during the Late Pleniglacial (last glacial maximum) [7]. During the relatively cold and dry part of the Late Pleniglacial, savannah vegetation extended in Suriname, replacing the rain forest in the interior. During (and part of) the LGM savannah vegetation replaced wet forest at the entire present coastal area of Suriname [6,35]. It was estimated by Van der Hammen and Absy [36,37] and Van der Hammen [37] that precipitation in Suriname during the LGM was about 500 to $1000 \mathrm{~mm} / \mathrm{yr}$., which was needed in order to sustain a natural grass savannah and 1000 to $1500 \mathrm{~mm} / \mathrm{yr}$. for a mixed grass/woodland savannah. The rainfall regime was also more seasonal with a prolonged dry season. This is in accordance with predictions of 750 to $1500 \mathrm{~mm} / \mathrm{yr}$. for the LGM by global climate models [38].

During the Late Glacial (13-11.3 ka), the climate of northern South America became wetter, the rivers carried an increasing quantity of water and a new cycle of sediment deposition began and continued into the Holocene. The increase in water level in the rivers seems to have been considerable, locally leading to temporal permanent inundation of the (upper to) middle river valleys [39-41].

\subsubsection{Holocene}

Records from the savannas of eastern Colombia, indicate that there was a shift from dry early Holocene to wetter environments after $\sim 6 \mathrm{ka}$ [42]. This can be explained by changes in the position of the Inter Tropical Convergence Zone. During the early Holocene, the ITCZ apparently had a more northerly position than today $[43,44]$, causing dry conditions in the savanna. The ITCZ shifted southwards during the mid- and late Holocene, leading to more precipitation in the savannas.

During the early Holocene (12 to $6 \mathrm{ka} \mathrm{BP}$ ), sea level rose from a depth of more than $100 \mathrm{~m}$ to the present level $[45,46]$. Sea level rise slowed down between 6 and $7 \mathrm{ka}$ BP (Figure 2) [47]. Precipitation increased during the early Holocene. Rainfall still was concentrated in the summer monsoon, which may explain the persistency of the savannahs during 
the early Holocene. The average yearly temperature was about 5 to $6{ }^{\circ} \mathrm{C}$ lower than today during the LGM $[36,38]$. The yearly actual evapotranspiration was $15 \%$ lower than today, which was approximately $1300 \mathrm{~mm} / \mathrm{yr}$. in Suriname [38].

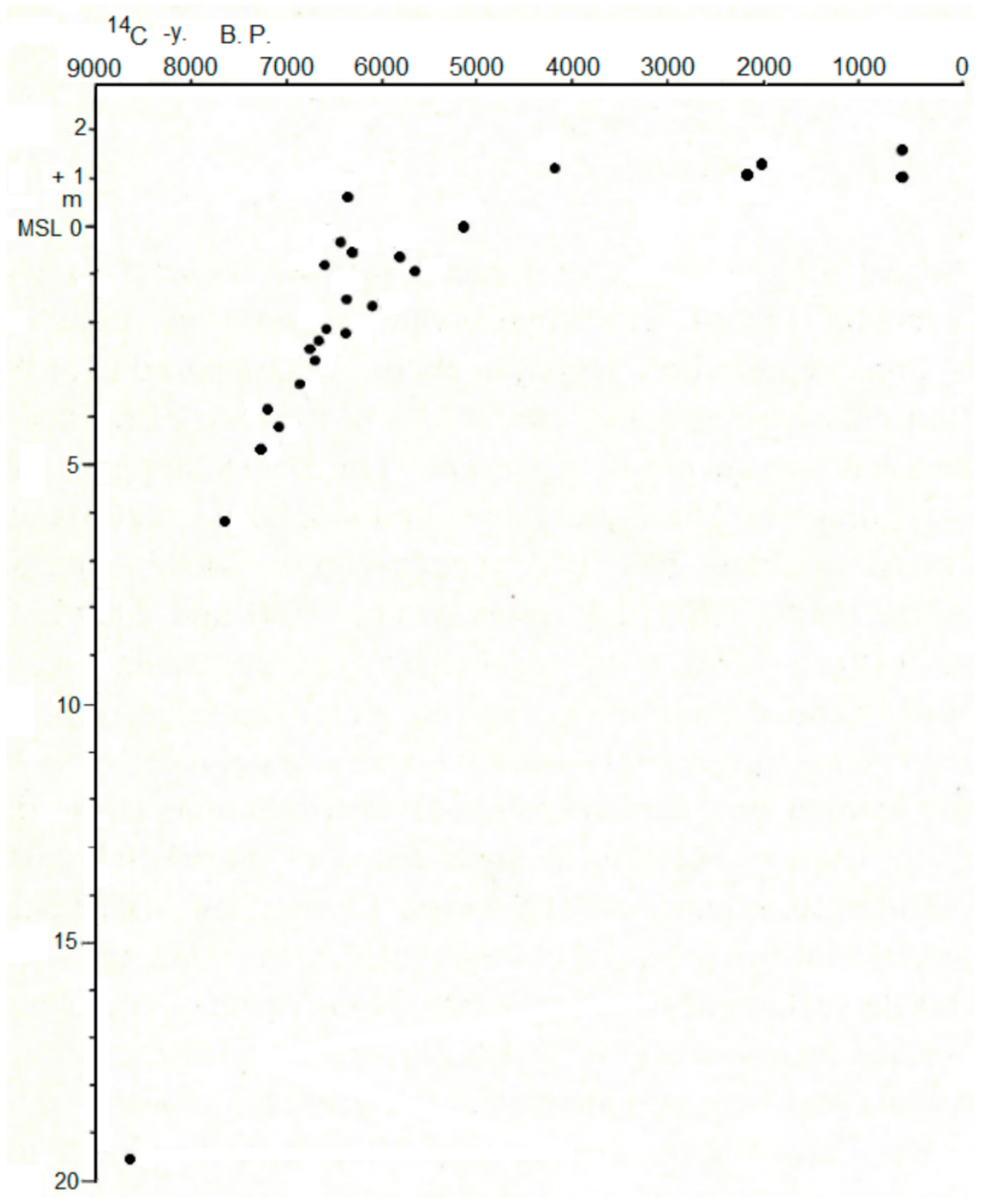

Figure 2. Sea level rise at the Suriname coast (modified after [46]).

\section{Materials and Methods}

In the practically inaccessible hinterland of Suriname, aerial map analysis is a very important research method. This is based on the existence of a relationship between soil and landscape. The geology of the study area is also involved in the analysis. However, height and slope differences are at least as important as soil data in the evaluation of the landscape. The research methods of this study consisted of desktop, fieldwork, and laboratory parts.

A preliminary map analysis was made of the study area. This map analysis was aimed at distinguishing geomorphological units (e.g., terraces) that differ markedly from each other in terms of height. Subsequently, a limited number of observations were made to check the preliminary map data to obtain detailed information about the morphometry of the different landscapes (height and slope differences, etc.) and the soil characteristics.

Fieldwork was done from the river inland. On selected locations boreholes were made using an auger and a gouge to determine terrace sedimentary successions and to collect 
samples. The locations of the boreholes were chosen in parts of the various terraces that were representative of the landscape. This means that data obtained from the drilling survey was considered to be representative of the remaining area.

Samples from five boreholes were selected for analyzing the sediment texture in the laboratory. A Sympatec HELOS laser diffraction machine was used for the particle size analyses, ranging from $0.1 \mu \mathrm{m}$ to $3500 \mu \mathrm{m}$.

Before collecting the field data, terraces were mapped in the upper, middle, and lower Suriname River valley stretches with the aid of a Space Shuttle Digital Eevation Model (SRTM DEM) and topographic maps. Historical topographic maps revealed that inland residents used the terraces for laying out their agricultural lands. This information was used to infer terraces in the midstream part of the Suriname River valley, because this part is nowadays submerged due to the construction of the Afobaka dam.

The resulting terrace maps were largely based on a map of the upper Suriname and Saramacca River areas produced by Balsem and Rhebergen [48] in the framework of a geomorphological-soil science cooperation project between the Soil Survey Institute of Suriname (DBK) and the Vrije Universiteit Amsterdam (VU), as wel as on a detailed study of the upper Suriname River valley, which was also part of the Soil Mapping Service (Dutch: Dienst Bodem Kartering)/Vrije Universiteit DBK/VU project by Kips and Snel [49].

\section{Results}

\subsection{General Characteristics of the Terraces}

For practical purposes, we divided the Suriname River valley into an upper (Figure 3), middle (Figure 4), and lower valley part (Figure 5), corresponding, respectively, with the part upstream from the Afobaka storage lake, the Afobaka storage lake itself, and the part from the Afobaka dam to Cassipora. The terrace remnants were plotted at a longitudinal profile (Figure 6). Apart from potential correlations, the profile also showed that the current river profile has three important knickpoints.

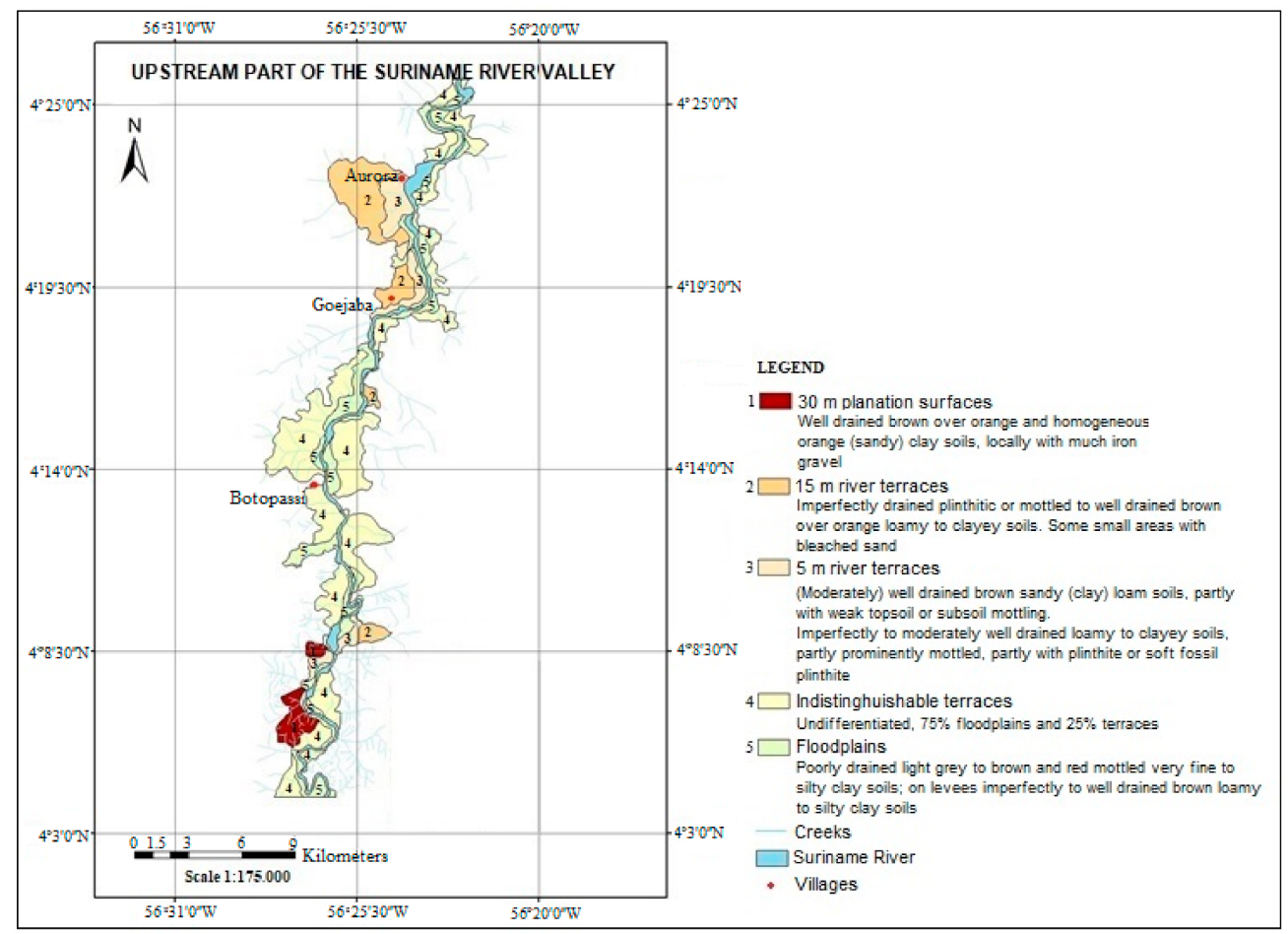

Figure 3. Map of terraces along the upstream river valley part of the Suriname River. 


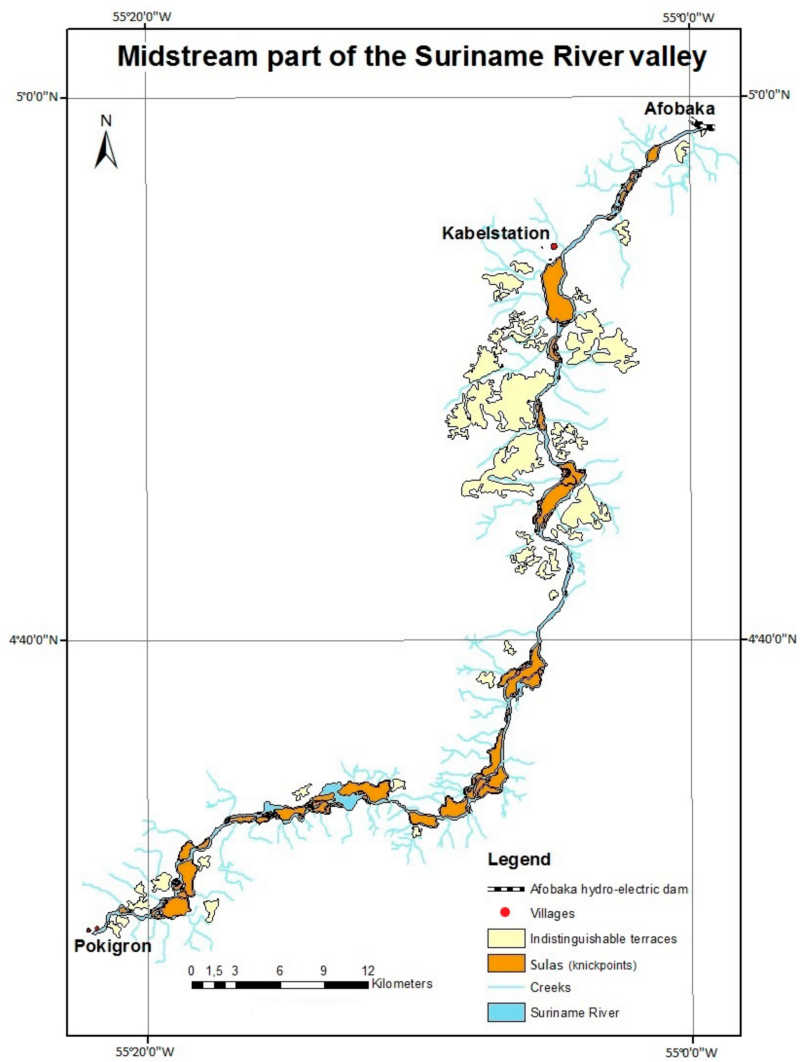

Figure 4. Inferred terraces along the mid-stream river valley part of the Suriname River, now submerged in Lake Afobaka.

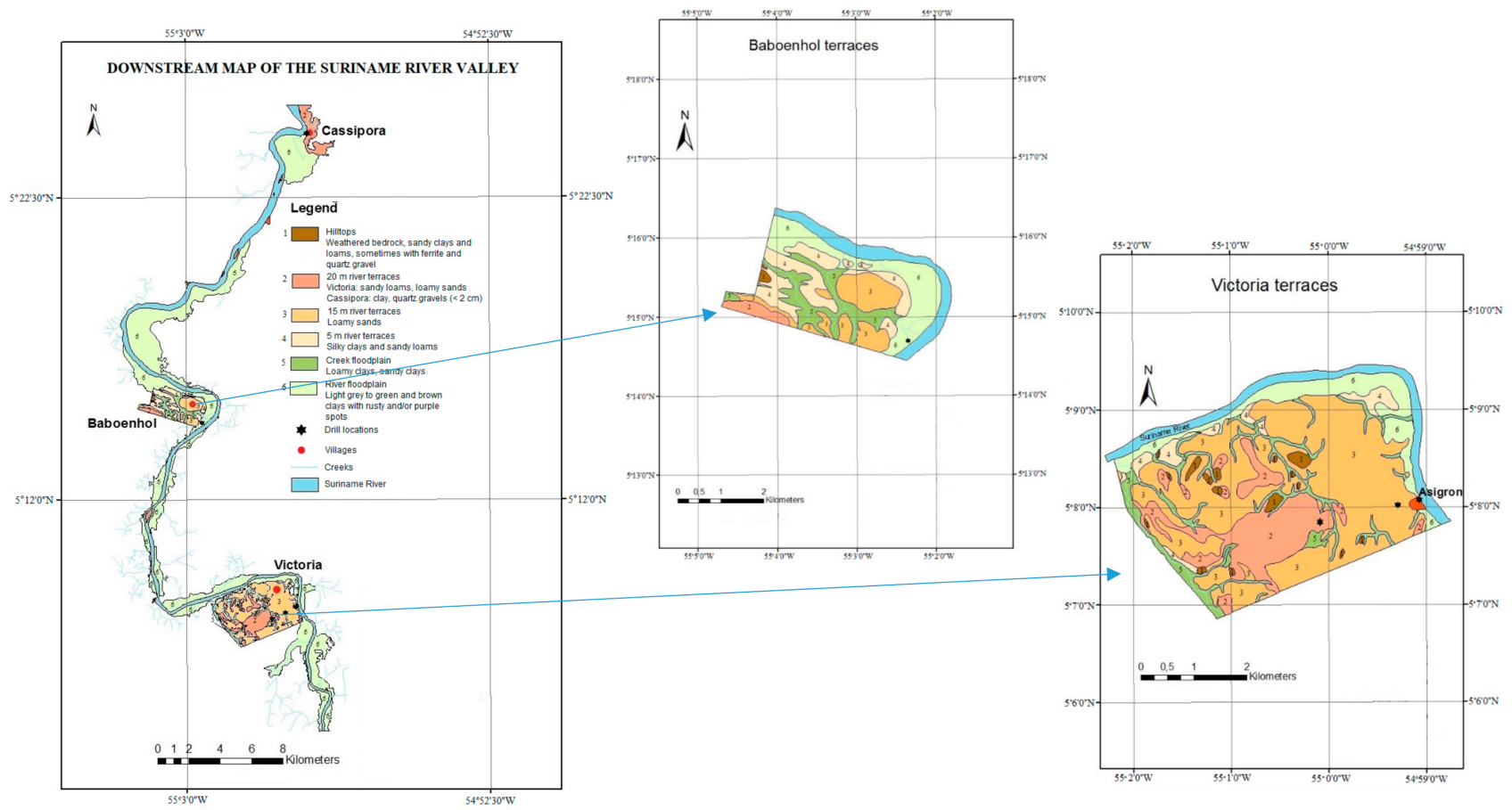

Figure 5. The downstream part of the Suriname River valley. 


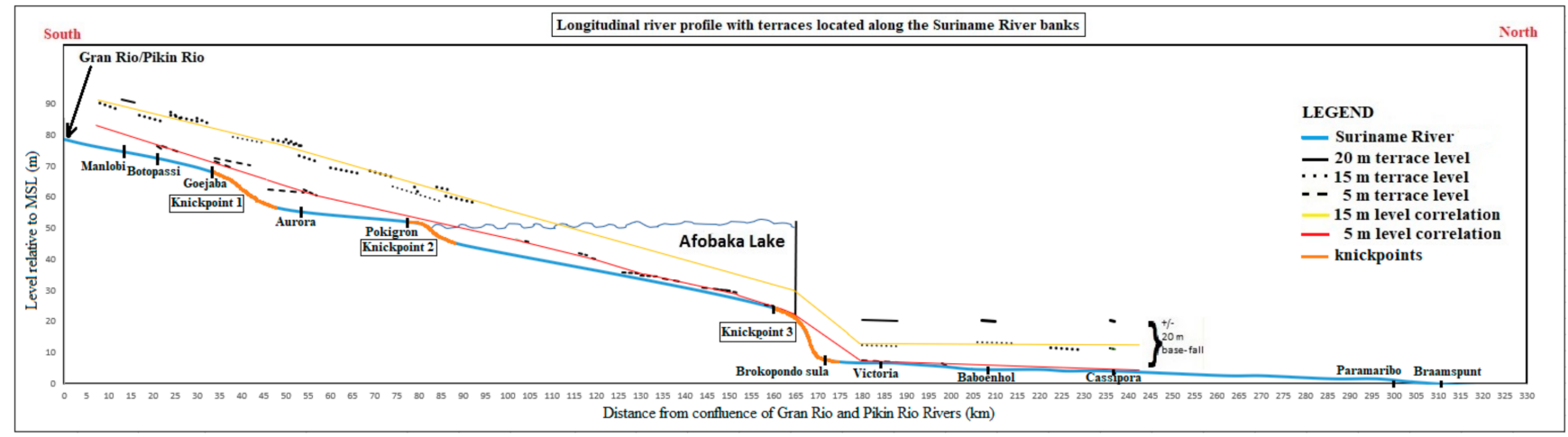

Figure 6. Longitudinal profile of terrace remnants and their correlation along the Suriname River valley. Knickpoints coincide with larger sulas (cataracts).

\subsection{Upper River Valley Part}

The terrace map of the upper river valley (Figure 3) is based on maps of the upper Suriname and Saramacca River areas by Balsem and Rhebergen [48]. They distinguished a $20 \mathrm{~m}, 15 \mathrm{~m}$, and a $5 \mathrm{~m}$ high terrace level. The 20- $\mathrm{m}$ terrace level has a relief up to $25 \mathrm{~m}$ and slopes up to $18 \%$, and consists of regolith of mainly felsic rocks, and local river sediments. The $15 \mathrm{~m}$ terrace level has an undulating morphology with a relief up to $15 \mathrm{~m}$ and slopes up to $8 \%$, consisting of Pleistocene river deposits (50\%) (fluviatile sediments) and regolith of mainly felsic rocks (50\%). The terrace deposits have a thickness of 0.5 to $4 \mathrm{~m}$. The $5 \mathrm{~m}$ terrace level remnants are almost flat plains with depressions, relief up to $5 \mathrm{~m}$, and slopes up to $4 \%$. They consist of relatively thin fluviatile loam deposits.

Kips and Snel [49] also distinguished a 30-m high level (Figure 3) with a sediment sequence of 3.5 to $5 \mathrm{~m}$ in thickness. The deposits contain fine, rounded gravel and show a fining upwards sequence of loamy sand at the bottom, passing into (sandy heavy) loam at the top of the sequence.

The sediments in the present floodplain differ considerably from the three levels, and according to a few deep auger drillings, consists mainly of silty to heavy clay without any fining upwards sequence. At some locations the floodplain and the $5 \mathrm{~m}$ terrace level are absent, and the 15- $\mathrm{m}$ and 20- $\mathrm{m}$ terrace levels directly border the river channel. According to the Geological Mining Services of Suriname (GMD) the river terraces in the upper reaches have developed entirely on granitoid and gneissic rocks of the Precambrian basement.

The terrace remnants mapped by Balsem and Rhebergen [48] and Kips and Snel [49] are plotted in the longitudinal profile of Figure 6. Based on the correlation of the remnants, we conclude that three levels are present, at 5, 15, and $20 \mathrm{~m}$ above the present-day river level.

\subsection{Middle River Valley Part}

Up to now, little is known of terraces along this part of the river, especially regarding their height levels. The geological map of sheet Kabel (31) by D'Audretsch [50], made before the construction of the Afobaka dam, shows a continuous strip of terraces, all developed on tonalitic granitoid rocks. D'Audretsch [50] gives a terrace height of $10 \mathrm{~m}$ above low water level, on which the Maroon villages were built. Martin [51] measured the height of 7 Maroon villages on a terrace situated between 5 and $9 \mathrm{~m}$ relative to the river level. Whether higher terrace levels are also present is unknown, as most earlier researchers mainly surveyed from the river. In the present research, additional lower terrace fragments (Figure 6) were derived based on the locations of former farmlands depicted on historical maps.

According to D'Audretsch [50], the present floodplain is up to $6 \mathrm{~km}$ wide. Locally, low levees occur in the outer bends. Where the river incises in its own deposits a gravel 
layer resting on weathered basement rock is exposed. The fill of midstream part of the river valley consists of cream-colored to yellowish clay.

\subsection{The Lower River Valley Part}

According to our analyses, the main terrace levels along the downstream reach are situated at heights of $20 \mathrm{~m}, 15 \mathrm{~m}$, and $5 \mathrm{~m}$ above the mean water level of the river. They are particularly well developed at three locations, which we studied in detail, i.e., from south to north the remnants of the Victoria terraces, the Baboenhol terraces, and the Cassipora terraces (for location see Figure 5). According to the geological map, the Victoria and Baboenhol terrace remnants are developed on basement rocks, whereas the Cassipora terrace remnant sits on Zanderij Formation sands (Figure 7).

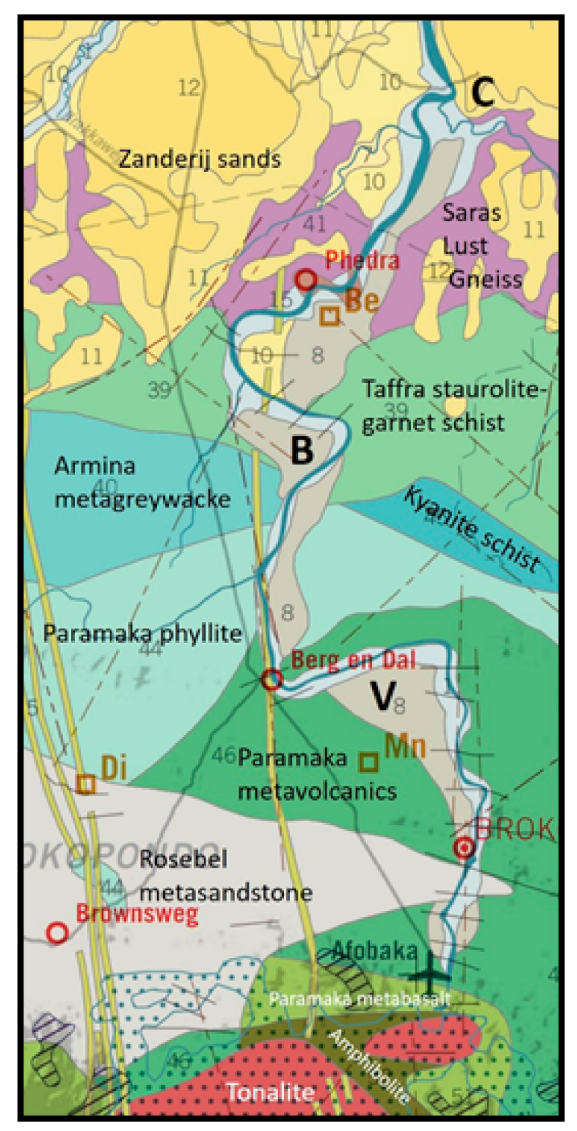

Figure 7. Geological map with Zanderij Formation indicated in yellow. Other colors represent basement rocks ( $\mathrm{V}=$ Victoria; $\mathrm{B}=$ Baboenhol; $\mathrm{C}=$ Cassipora) .

\subsubsection{The 20-m Terrace Level $\left(\mathrm{T}_{20 \mathrm{~m}}\right)$ at Victoria}

The 20-m terrace level situated at Victoria consists of fluvial deposits and is developed on hard rock, while at Cassipora it is developed on the Zanderij Formation of Pliocene age. The lithology at the base at Baboenhol is unknown, but is likely also hard rock. At Baboenhol and Victoria, the topography of the upper surface of this level is irregular as a result of numerous incised local creeks (Figure 5). The height of the terrace level increases with increasing distance from the river. At Victoria, transitions from the $15 \mathrm{~m}$ terrace level to the 20-m terrace level occur gradually. Compared to Cassipora, the sands of the 20-m terrace level at Victoria are loamier (Figure 7).

The 20-m terrace level located at Victoria, on the left bank, extends to approximately $1.5-2 \mathrm{~km}$ inland from the river. The topography is fragmented by small, incised creeks, and shows a gradual increase in height. Its subsurface consists, from top to bottom, of 
sandy loams with gravel, loamy sands, and loamy sands with gravel (Figure 8 ). The sands resemble those of the Zanderij Formation, suggesting they could be related.

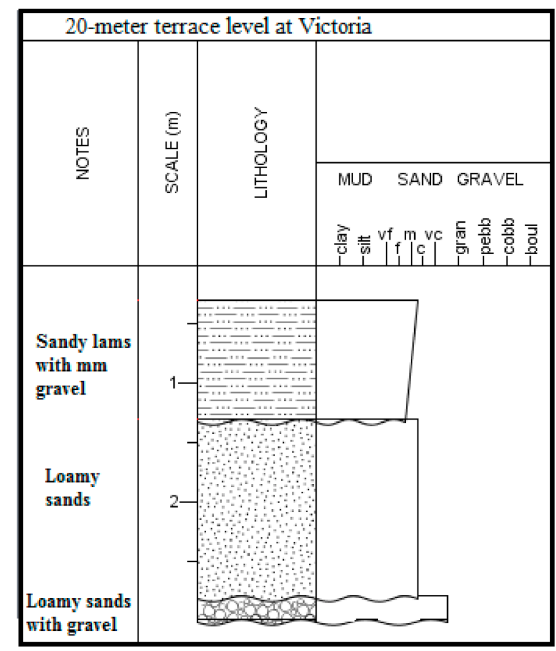

Figure 8. Sediment log of drilling core at the $20 \mathrm{~m}$ terrace level at Victoria.

The 20-m terrace level at Baboenhol, located at the left bank of the river (Figure 5), is also fragmented by incising tributary creeks. However, it also shows very different morphological characteristics compared to the 20-m level at Victoria. Starting from the river, the land surface rapidly increases in height from 5 to $15 \mathrm{~m}$. There is a sharp transition from the $15-\mathrm{m}$ to the $20-\mathrm{m}$ terrace levels.

The width of the $20-\mathrm{m}$ terrace levels is about $0.5 \mathrm{~km}$. A sharp transition from the floodplain (at $1 \mathrm{~m}$ ) and 20-m terrace levels over a distance of circa $50 \mathrm{~m}$ occurs at Cassipora (right bank). Both locations had sharp transitions. Baboenhol and Cassipora (right bank) are situated in the outer river bends, while Victoria, with gradual transitions, lies in an inner bend.

The shallow subsurface of the 20-m terrace level at Cassipora consists of fluvial fine and angular quartz gravels, overlain by a clay deposit. The gravels show a fining upward trend (Figure 9). The gravel clasts have a diameter of up to $2 \mathrm{~cm}$. They are interpreted as part of the Pliocene Zanderij Formation. The overlying clay deposits has orange (oxidized) and green colored (reduced) spots, which are related to soil formation.

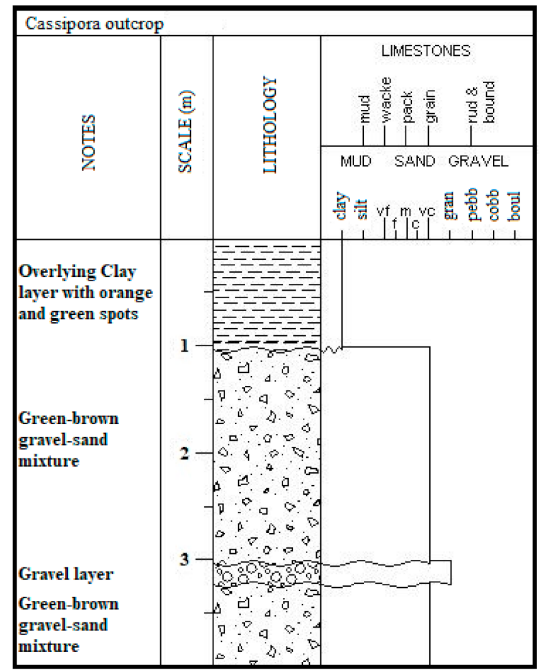

Figure 9. Sediment log of the outcrop at Cassipora. 


\subsubsection{The $15-\mathrm{m}$ Terrace Level $\left(\mathrm{T}_{15 \mathrm{~m}}\right)$}

The width of the $15-\mathrm{m}$ terrace level ranges from about 0.25 to $0.5 \mathrm{~km}$. The upper surface of the 15-m terrace level ranges between 10 and $20 \mathrm{~m}$ above the river, but is mostly at about $15 \mathrm{~m}$, which corresponds with the findings of Kips and Snel [49] in the Upper Suriname River valley. The terrace landscape is undulating and locally incised by some large creeks in shallow fairly flat valleys.

\subsubsection{The 5-m Terrace Level $\left(\mathrm{T}_{5 \mathrm{~m}}\right)$}

Along the downstream part of the Suriname River valley, the $5 \mathrm{~m}$ terrace group is present at Victoria and Baboenhol. At Cassipora the floodplain is absent and the present outcrop of the Zanderij Formation directly borders the river. The average width of the 5-m terrace level goes up to $50 \mathrm{~m}$, but where it is narrow the $5-\mathrm{m}$ passes gradually into the $15-\mathrm{m}$ terrace level. The upper part of the terrace deposits consists of clays locally with rusty or purple spots (soil formation) (Figure 10).

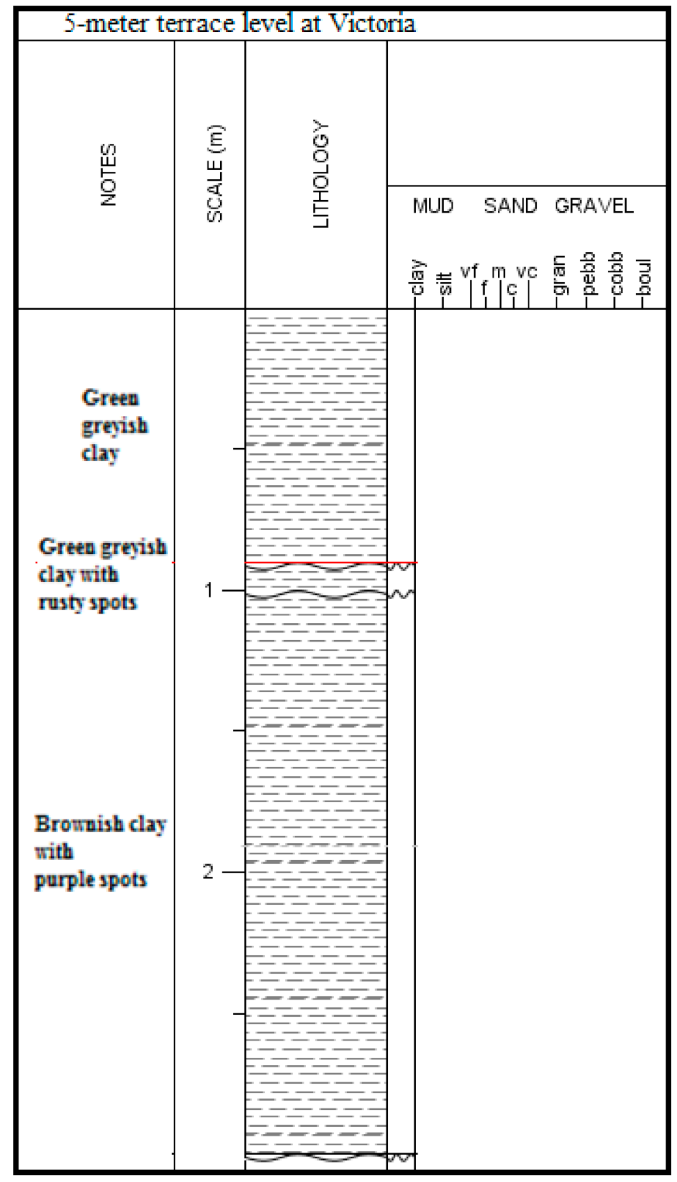

Figure 10. Sediment log of drilling core in the 5-m terrace level at Victoria.

At Brokopondo Sula, further upstream between Victoria and the Afobaka Dam, a 5- $\mathrm{m}$ terrace level is present on an island in the middle of the river. A profile across the island was obtained for the purpose of exploring a possible dam site [52]. The profile shows an irregular bedrock surface at 7 to $12 \mathrm{~m}$ depth, covered by a fluvial fining upward sequence, with coarse sand at the bottom and loamy sand at the top (Figure 11) [52]. 


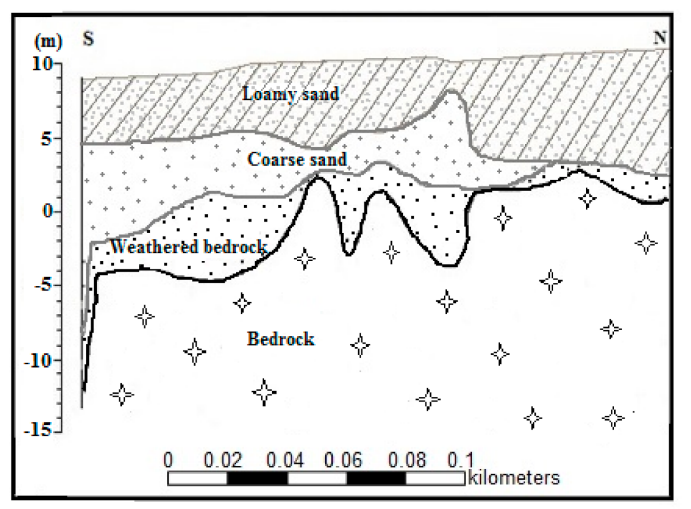

Figure 11. Cross-section through the island at the Brokopondo Sula (modified after Bleys [52]).

\section{Discussion}

The studied section of the Suriname River valley shows generally three terrace levels above the present mean water level. In the most upstream and downstream parts, the highest level is at $20 \mathrm{~m}$ above river level. Information about higher terrace levels in the now submerged intermediate part (Afobaka Lake) is lacking, so it is not clear whether these levels are the same. In view of the fact that water levels in the Suriname River valley may vary up to $7 \mathrm{~m}$ between high and low discharges [50], estimations of the height of the terraces above river level may have a large error margin.

We correlated the 20-m level in the upstream part to the level at the same height in the downstream part for two reasons: (1) this correlation follows the shape of the present-day longitudinal profile, including the sulas; and (2) the number of terrace levels is the same in the upstream and downstream parts. The first argument assumes that the sulas are a permanent feature of the fluvial longitudinal profile, for which we provide arguments below.

The consistently presence of terraces at the 20,15 , and $5 \mathrm{~m}$ levels at both the up- and downstream parts of the Suriname River valley (Figure 12), can be explained by lowering of long-term eustatic sea level and/or low amount of uplift. There is more evidence of recent tectonic movement than originally thought, primarily as a result of rift shoulder development due to the separation of South America and Africa, and the development of the Takutu failed arm along the border between Suriname and Guyana. Data from northeastern Brazil suggest a possible uplift of $20 \mathrm{~m}$ in the Quaternary [53]. Cenozoic uplift of the Bakhuis Horst in western Suriname along reactivated Precambrian faults parallel to the Takutu rift is even recorded in seismic sections in the coastal plain [54,55].

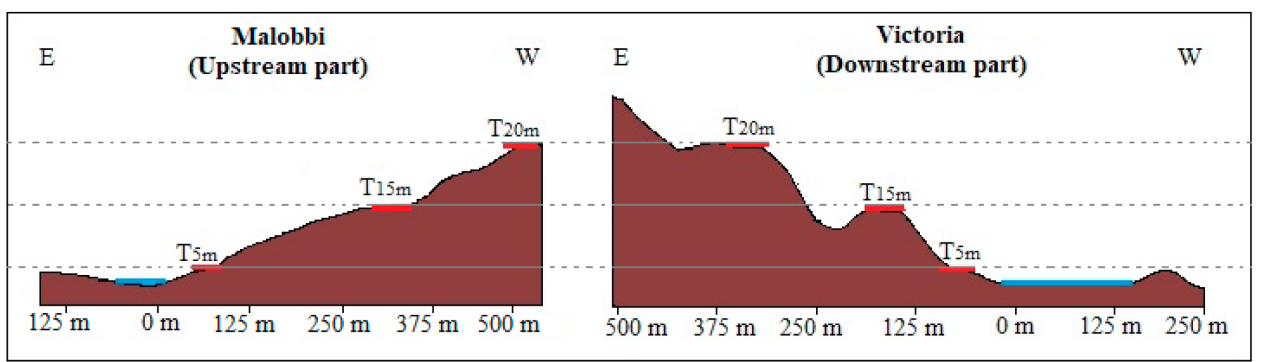

Figure 12. Cross-sectional topographic profiles of Malobbi (Upstream part) and Victoria (Downstream part) with correlated terrace levels.

\subsection{A Model for Terrace Evolution in the Upstream and Middle Parts}

Terrace development in the humid tropics is largely attributed to the effects of climate change. During glacials, the climate is relatively dry, because less water-vapor is available in the atmosphere, causing reduced precipitation. In contrast, interglacial climates are relatively wet. Reduction of precipitation during a transition from an interglacial to a glacial 
period leads to the conversion of the dense tropical forest into savannah vegetation. At the same time, because the surface is less covered with vegetation during glacials, more erosion occurs, leading to more sediments available for fluvial transport. Thus, fluvial sediment load increases, whereas transport capacity decreases. This results in sediment storage (aggradation) in the river valleys and raising of the river valley floor. During interglacials rivers incise, because the climate is relatively wet, resulting in increased precipitation and vegetation cover $[56,57]$.

During the Quaternary many glacial/interglacial cycles have occurred, and some rivers, such as the Meuse in the Netherlands, show a terrace for each climate cycle, up to 30 for the whole Quaternary [58].

In general, the preservation of terraces in a terrace staircase requires a long-term incision. In case of the Suriname River valley, the 20-m of incision during the Pliocene and Quaternary is insufficient to produce a visible staircase of about 30 terraces, whereby each would represent a climate cycle.

The long-term 20-m incision since the Pliocene requires an explanation. It may have been caused by the long-term eustatic sea level fall since the Pliocene [59] and/or by uplift. A slow and relatively low amount of uplift may have resulted from the rifting processes that led to the formation of the Atlantic Ocean (passive margin uplift). According to studies in north-east Brazil [53] rift shoulder uplift and denudation along the Atlantic coast due to rifting since the Cretaceous amounted to $10 \mathrm{~m} / \mathrm{Ma}$, that is $20 \mathrm{~m}$ for the whole Quaternary. Alternatively, the differential uplift can be explained as a result of erosional isostasy of the hinterland [60]. The small amount of uplift and the consequent limited vertical separation of the terraces can be explained by absence of lower crustal flow in of this cratonic crust [16].

Knickpoints in the upstream part of the river valley are present in the present-day longitudinal profile, particularly at Goejaba and Pokigron (Figure 6). The knickpoint at Goejaba is likely caused by a northeast-southwest oriented dolerite dyke that cuts across the river and acts as a sula, whereas the knickpoint at Pokigron is controlled by the Kwai-Kwai sula as a result of differential weathering. Sulas are very stable and nonmigrating on geological timescales. In non-tropical conditions, knickpoints can be abraded by fluvial gravel and sand. However, under tropical conditions such as in Suriname, chemical weathering in the basement is very intense and produces only sand and clay. Any local gravel will also be rapidly transformed into sand and clay before reaching the sulas. Sand and clay are largely transported in suspension, and they are too fine to be able to significantly abrade the sula knickpoints [24].

The situation at the knickpoints may have been different in glacial times with semiarid climatic conditions. The fining upwards sequences in the terraces often show rounded gravel at their base, suggesting less intense weathering in the drainage basins and more bedload transport in the channels. Under such conditions rocky knickpoints can therefore be lowered by the erosive power of the bedload. This is suggested by the northernmost knickpoint, the Brokopondo sula, just downstream of the Afobaka Lake (Figure 6). The island in the middle of this sula consists of a buried irregular rock outcrop covered by sediments belonging to the 5-m terrace level. This suggests that the buried rock surface has been a sula in its own right in glacial times, which probably first suffered erosion by the increased bed load and then became covered by the fluvial fining upwards sequence. This possibly encompasses a smoother length profile of the river in glacial times than in the present interglacial times. Unfortunately, the absence of datable material in the terrace sediments so far precludes confirming this scenario.

\subsection{A Model for Fluvial Development in the Downstream Part}

The upstream influence of sea level fluctuation is likely to be limited [10]. Many rivers today, such as those around NW Europe, flow in valleys that formerly extended over a wide continental shelf, but their lower reaches were inundated and submerged by the Holocene marine transgression [8]. 
While the river valleys fill-up in the upstream part of the river during a glacial, in the downstream part they are incising due to sea level fall, and vice-versa, during an interglacial (e.g., [61]). The location of the transition between incision and aggradation during a certain climatic situation, the terrace-intersection likely is located at those points in the river valley where the most downstream bedrock-controlled cataracts (sulas or rapids) occur. These sulas limit the upstream migration of sea level induced knick-points. In the case of the Suriname River valley, they are situated at the transition from Guiana Shield bedrock to the coastal plain deposits, at the Brokopondo Sula (Figure 12).

For example, eustatic sea level dropped to about $120 \mathrm{~m}$ during the LGM. During this period the Suriname coastline was situated at 130 to $150 \mathrm{~km}$ north of the present coastline [48], leading to exposure of the Suriname Continental Shelf and, as a consequence, the extension of the downstream part of the Suriname River valley. From the river mouth, incision migrated landward, incising into the shelf and into the previous river floodplain of the present lower Suriname River valley.

From the LGM to the early Holocene, rivers and creeks close to the sea were very deeply incised $(10-30 \mathrm{~m})$. Erosion also took place in the Old Coastal Plain and on the shelf of Suriname [46,62-64]. Moreover, the large Suriname River must have eroded into the sediments of the coastal plain and continental shelf. Core drillings by Groen (2002) show that near Paramaribo the base of the paleochannel of the Suriname River valley was about $-35 \mathrm{~m}$ (below $\mathrm{msl}$ ). After the steep sea level rise at the beginning of the Holocene (12 ka BP), the coastline shifted circa $20 \mathrm{~km}$ landward of its present position. Sea level reached its current level at $6.5 \mathrm{ka} \mathrm{BP}[45,46]$. Since then, the coastline shifted seawards $10 \mathrm{~s}$ of kilometers due to coastal aggradation.

In contrast, for the middle and the upper part of the river valley it is very unlikely that eustatic sea level changes have led to the formation of terraces (i.e., deposition during highstands and incision during lowstands), as the Brokopondo Sula forms a rock sill that cannot be cleared away by headward river erosion.

The $5 \mathrm{~m}$ terrace level fragments at Victoria and Baboenhol, i.e., downstream of the Brokopondo sill, theoretically could represent a terrace formed as a result of the 7-m Eemian highstand that also formed the Old Coastal Plain. These terrace deposits do not show the common fining upwards sequence of the upstream 5-m terrace levels but consists primarily of clay (although the depth of the augering was only $3 \mathrm{~m}$ ). In a similar situation near the mouth of the Marowijne River valley, marine clay was found in a $5 \mathrm{~m}$ terrace level profile in the Coropina Formation (Eemian) [5,65].

However, the Victoria 5-m terrace level is located at about $130 \mathrm{~km}$ from the mouth of the Suriname River valley, measured along the river channel (100 km as the crow flies), and the nearest Coropina (Eemian) marine deposits of the Old Coastal Plain are $40 \mathrm{~km}$ north from Victoria. Moreover, the Old Coastal Plain marine deposits do not reach higher elevations than $7 \mathrm{~m}$ above present sea level, whereas the Victoria $5-\mathrm{m}$ terrace level is at $12 \mathrm{~m}$ above present sea level. Therefore, we conclude that that the 5-m terrace level at Victoria is a fluvial deposit.

As discussed above, the third knickpoint in the Suriname River valley at the Brokopondo sula shows a fining upwards fluvial sequence on top of an irregular bedrock profile [52]. This sula was buried by fluvial sediments of the $5 \mathrm{~m}$ level during the last glacial semiarid period and dissected during the present humid interglacial. Fluvial deposition during the last glacial apparently went downstream beyond the last knickpoint and is probably also responsible for the 5-m terrace levels at Victoria and Baboenhol. Therefore, it is unlikely that any of the studied terraces in the study area has formed as a result of Eemian highstand deposition and Last Glacial dissection.

\section{Conclusions}

Like other rivers in cratonic drainage basins covered with exclusively tropical rainforest, the Suriname River at present is characterized by the virtual absence of bedload transport, because the deeply weathered basement does not provide coarse-grained sed- 
iment to the rivers. Cataracts (sulas) are formed in the river channel where interglacial incision touches subsurface rock weathering fronts. The absence of bedload forces the Suriname river to avoid the rocky obstacles instead of eroding them away, leading to multichannel cataracts, which only in plain view resemble braided river patterns. However, they are stable rocky features instead of moving gravel and sand bars. The cataracts represent important knickpoints in the length profiles of the rivers.

In the Suriname River in the Guiana Shield, the presence of several gravel-bearing terrace levels above the present flood plain suggests that in glacial times, in this region, were characterized by semi-arid climatic conditions with savannah-type vegetation, fluvial dynamics differed considerably from the present ones. Three terrace levels at 20,15 and $5 \mathrm{~m}$ above present mean water level were studied in three sectors of the river: an upstream part, a middle part (now submerged below a storage lake), and a lower part. The consistent height difference between these levels and their length profiles being roughly parallel to the present one suggests that they represent major stages in the development of the river basin. The consistent presence of terraces at the 20,15 , and $5 \mathrm{~m}$ levels at both the up- and downstream parts of the Suriname River valley can be explained by lowering of long-term eustatic sea level and/or low amount of uplift. As dissection is argued to have started already in the late Pliocene or early Pleistocene, the terrace staircase may represent many more than three climatic cycles. However, because of the absence of datable material individual cycles cannot be resolved as of yet.

The presence of gravel in the fluvial terraces could imply that the role of the knickpoints was less prominent than at present. An island in the northernmost knickpoint, the Brokopondo sula, shows a buried rocky surface under a fining upwards sequence belonging to the $5 \mathrm{~m}$ terrace level, suggesting that many cataracts may have suffered bedload erosion indeed during glacial times, becoming covered with so much sediment that their knickpoint function became less effective. As a result, glacial length profiles could be smoother than the present one.

While in the upper part of the river valley the role of upstream controls, notably climatically induced changes in vegetation cover and sediment delivery are obvious, in the lowermost sector of the river the role of downstream controls, especially sea level change must also be discussed. Theoretically, the terraces in this sector could also represent fluvial deposition during sea level highstands and dissection by headward erosion during lowstands. However, even the $5 \mathrm{~m}$ terrace levels here are situated at $12 \mathrm{~m}$ above present sea level, whereas the oldest marine terrace in the Old Coastal Plain does not reach above $7 \mathrm{~m}$ above sea level. Moreover, the distance to the coast of the northernmost terraces is over $100 \mathrm{~km}$, far beyond any evidence of past sea levels. The presence of fluvial deposits on the most downstream knickpoint suggests that the terrace intersection must be situated further north than the present study area.

Author Contributions: Conceptualization, K.S.G. and R.T.V.B.; investigation, K.S.G. and R.T.V.B.; methodology, K.S.G. and R.T.V.B.; supervision, R.T.V.B. and S.B.K.; writing—original draft, K.S.G.; writing-review and editing, K.S.G., R.T.V.B., and S.B.K. All authors have read and agreed to the published version of the manuscript.

Funding: This research was funded by the Treub Company (The Netherlands), project code Treub2017 b_vanBalen, and the Suriname Conservation Foundation (Suriname).

Institutional Review Board Statement: Not Applicable.

Informed Consent Statement: Not applicable.

Data Availability Statement: Data is contained within the article. The data presented in this study are available in "The Interplay between Tectonic Activity, Climate and Sea-Level Change in the Suriname River Valley, Tropical South America". 
Acknowledgments: We would like to thank Riad Nurmohamed and the Suriname Conservation Foundation. Moreover, a big thanks to Johan Abelintie, villager of Victoria, and the following bachelor students from the Anton de Kom University who helped during field visits: Noel Sardjoe, Arantxa Lieveld, Sharan Bhajan, Kishan Ramdas, Sunaina Pirthipal, Shanice Pique, Saerah Sastrokarijo, Cherishma Beni, Zeinab Abdoelbasir, and Ralph Gogli. Also, a special thanks to Christina Ngai and Roetoe Lugard of the Geological Mining Service Suriname (GMD), Donovan Bogor from the National Institute for Environmental Development and Research in Suriname (Nimos), and Dana Artist from Gissat for making the various topographical maps available. Last but not least, a very special thanks to Melvin Pigot MSc. Your experience and knowledge of the study area was invaluable.

Conflicts of Interest: The authors declare no conflict of interest.

\section{References}

1. Latrubesse, E.; Stevaux, J.; Sinha, R. Tropical rivers. Geomorphology 2005, 70, 187-206. [CrossRef]

2. Garner, H.F. Rivers in the making. Sci. Am. 1967, 216, 84-94. [CrossRef]

3. Zonneveld, J.I.S. Sulas and sula complexes. Gottinger Geogr. 1972, 93-105.

4. Bakker, J.P. Die Flussterrassen Suriname als Hinweise auf etwas trocenere Klimate während der Quartären Eiszeiten. Acta Geog. Debrecina Landscape Environ. 1968, 7, 9-17.

5. De Boer, M.W.H. Landform and Soils in Eastern Surinam (South America); Pudoc: Wageningen, The Netherlands, $1972 ;$ p. 169.

6. Van der Hammen, T. A Palynological Study on the Quaternary of British Guiana; Leidse Geologische Mededelingen: Leiden, The Netherlands, 1963; pp. 125-180.

7. D'Apolito, C.; Absy, M.L.; Latrubfesse, E.M. The Hill of Six Lakes revisited: New data and re-evaluation of a key Pleistocene Amazon site. Quat. Sci. Rev. 2013, 76, 140-155. [CrossRef]

8. Bridgland, D. River terrace systems in north-west Europe: An archive of environmental change, uplift and early human occupation. Quat. Sci. Rev. 2000, 19, 1293-1303. [CrossRef]

9. Zeuner, F.E. The Pleistocene Period, Its Climate. Chronology and Faunal Successions; Ray Society: London, UK, 1945.

10. Schumm, S.A. River response to baselevel change: Implications for sequence stratigraphy. J. Geol. 1993, 101, 279-294. [CrossRef]

11. Pazzaglia, F.J.; Gardner, T.W. Late Cenozoic flexural deformation of the middle U.S. Atlantic passive margin. J. Geophys. Res. Space Phys. 1994, 99, 12143-12157. [CrossRef]

12. Merritts, D.J.; Vincent, K.R.; Wohl, E.E. Long river profiles, tectonism, and eustasy: A guide to interpreting fluvial terraces. J. Geophys. Res. Space Phys. 1994, 99, 14031-14050. [CrossRef]

13. Boll, J.; Thewessen, T.J.M.; Meijer, E.L.; Kroonenberg, S.B. A simulation of the development of river terraces. Z. Fur Geomorphol. 1988, 32, 31-45.

14. Maddy, D. Uplift-driven valley incision and river terrace formation in southern England. J. Quat. Sci. 1997, 12, 539-545. [CrossRef]

15. Stange, K.M.; Van Balen, R.; Vandenberghe, J.; Peña, J.L.; Sancho, C. External controls on quaternary fluvial incision and terrace formation at the Segre River, Southern Pyrenees. Tectonophysysics 2013, 602, 316-331. [CrossRef]

16. Westaway, R.; Bridgland, D.; Mishra, S. Rheological differences between Archaean and younger crust can determine rates of Quaternary vertical motions revealed by fluvial geomorphology. Terra Nova 2003, 15, 287-298. [CrossRef]

17. Augustinus, P.G.E.F. The Changing Shoreline of Surinam. Ph.D. Thesis, Rijksuniversiteit Utrecht, Utrecht, The Netherlands, 1978; p. 232.

18. Amatali, M.A. Climate and surface water hydrology. In Freshwater Ecosystems of Suriname; Ouboter, P., Ed.; Kluwer Academic Publishers: Amsterdam, The Netherlands, 1993; pp. 29-51.

19. Gersie, K.; Augustinus, P.; Van Balen, R. Marine and anthropogenic controls on the estuary of the Suriname River over the past 50 years. Neth. J. Geosci. 2016, 95, 419-428. [CrossRef]

20. Kroonenberg, S.; De Roever, E.; Fraga, L.; Reis, N.; Faraco, T.; Lafon, J.-M.; Cordani, U.; Wong, T. Paleoproterozoic evolution of the Guiana Shield in Suriname: A revised model. Neth. J. Geosci. 2016, 95, 491-522. [CrossRef]

21. Kroonenberg, S.B.; Melitz, P.J. Summit levels, bedrock control and the etchplain concept in the basement of Surinam. Geol. Mijnb. 1983, 62, 389-399.

22. Wong, T.; De Kramer, R.; De Boer, P.; Langereis, C.; Sew-A-Tjon, J. The influence of sea-level changes on tropical coastal lowlands; the Pleistocene Coropina Formation, Suriname. Sediment. Geol. 2009, 216, 125-137. [CrossRef]

23. Duba, D. Report on Water Balance Studies, Public Water Supplies and Sewage, net-4, Suriname-2200; World Health Organization: Geneva, Switzerland, 1972; p. 100.

24. Bakker, J.P.; Müller, H.J. Zweiphasige Flussablagerungen und Zweiphasenverwitterung in den Tropen unter besonderer Berücksichtigung von Surinam. Lautensach Festschr. Stuttg. Geogr. Stud. 1957, B. 69, 365-397.

25. Zonneveld, J.I.S. Waarnemingen langs de kust van Suriname. Tijdschr. K. Ned. Aardrijkskd. Genoot. 1952, 71, 18-31.

26. Hoorn, C.; Guerrero, J.; Sarmiento, G.A.; Lorente, M.A. Andean tectonics as a cause for changing drainage patterns in Miocene northern South America. Geology 1995, 23, 237-240. [CrossRef]

27. Dowsett, H.; Poore, R. Pliocene sea surface temperatures of the north atlantic ocean at 3.0 Ma. Quat. Sci. Rev. 1991, 10, 189-204. [CrossRef] 
28. Hooghiemstra, H.; Cleef, A.M. Pleistocene climatic change and environmental and generic dynamics in the North Andean montane forest and Paramo. In Biodiversity and Conservation of Neotropical Montane Forests; Churchill, S.P., Balslev, H., Forero, E., Luyeyn, J.L., Eds.; New York Botanical Garden: Bronx, NY, USA, 1995; p. 702.

29. Van Der Hammen, T.; Hooghiemstra, H. Neogene and Quaternary history of vegetation, climate, and plant diversity in Amazonia. Quat. Sci. Rev. 2000, 19, 725-742. [CrossRef]

30. Raymo, M.E.; Lisiecki, L.E.; Nisancioglu, K.H. Plio-pleistocene ice volume, antarctic climate, and the global 18o record. Science 2006, 313, 492-495. [CrossRef]

31. Haywood, A.M.; Dowsett, H.J.; Valdes, P.J.; Lunt, D.J.; Francis, J.E.; Sellwood, B.W. Introduction. Pliocene climate, processes and problems. Philos. Trans. R. Soc. A Math. Phys. Eng. Sci. 2009, 367, 3-17. [CrossRef] [PubMed]

32. Jansen, E.; Overpeck, J.; Briffa, K.R.; Duplessy, J.C.; Joos, F.; Masson-Delmotte, V.; Zhang, D. Palaeoclimate. Contribution of working group I to the fourth assessment report of the Intergovernmental Panel on Climate Change, 2007. In Climate Change 2007: The Physical Science Basis; Cambridge University Press: Cambridge, UK, 2007.

33. Molnar, P.; Cane, M.A. El Niño's tropical climate and teleconnections as a blueprint for pre-Ice Age climates. Paleoceanography 2002, 17. [CrossRef]

34. Baker, P.A.; Fritz, S.C. Nature and causes of Quaternary climate variation of tropical South America. Quat. Sci. Rev. 2015, 124, 31-47. [CrossRef]

35. Wijmstra, T.A. The Palynology of the Guiana Coastal Basin. Ph.D. Thesis, University of Amsterdam, Amsterdam, The Netherlands, 20 January 1971.

36. Van der Hammen, T.; Absy, M.L. Amazonia during the last glacial. Palaeogeogr. Palaeoclim. Palaeoecol. 1994, 109, $247-261$. [CrossRef]

37. Van Der Hammen, T. The pleistocene changes of vegetation and climate in tropical South America. J. Biogeogr. 1974, 1, 3-26. [CrossRef]

38. Kutzbach, J.; Gallimore, R.; Harrison, S.; Behling, P.; Selin, R.; Laarif, F. Climate and biome simulations for the past 21,000 years. Quat. Sci. Rev. 1998, 17, 473-506. [CrossRef]

39. Urrego, L.E. Sucesion Holocenica de un bosque de Mauritia flexuosa L.f. en el valle del Rio Caqueta (Amazonia colombiana). Colomb. Amaz. 1991, 5, 99-118.

40. Van Der Hammen, T.; Urrego, L.E.; Espejo, N.; Duivenvoorden, J.F.; Lips, J.M. Late-glacial and Holocene sedimentation and fluctuations of river water level in the Caquetá River area (Colombian Amazonia). J. Quat. Sci. 1992, 7, 57-67. [CrossRef]

41. Van Der Hammen, T.; Duivenvoorden, J.F.; Lips, J.M.; Urrego, L.E.; Espejo, N. Late quaternary of the middle Caquetá River area (Colombian Amazonia). J. Quat. Sci. 1992, 7, 45-55. [CrossRef]

42. Vélez, M.; Hooghiemstra, H.; Metcalfe, S.; Wille, M.; Berrío, J. Late Glacial and Holocene environmental and climatic changes from a limnological transect through Colombia, Northern South America. Palaeogeogr. Palaeoclim. Palaeoecol. 2006, $234,81-96$. [CrossRef]

43. Haug, G.H.; Hughen, K.A.; Sigman, D.M.; Peterson, L.C.; Röhl, U. Southward migration of the intertropical convergence zone through the holocene. Science 2001, 293, 1304-1308. [CrossRef]

44. Martin, L.; Bertaux, J.; Corrège, T.; Ledru, M.-P.; Mourguiart, P.; Sifeddine, A.; Soubiès, F.; Wirrmann, D.; Suguio, K.; Turcq, B. Astronomical forcing of contrasting rainfall changes in tropical South America between 12,400 and 8800 cal yr b.P. Quat. Res. 1997, 47, 117-122. [CrossRef]

45. Fairbanks, R.G. A 17,000-year glacio-eustatic sea level record: Influence of glacial melting rates on the Younger Dryas event and deep-ocean circulation. Nat. Cell Biol. 1989, 342, 637-642. [CrossRef]

46. Roeleveld, W.; Van Loon, A.J. The Holocene development of the young coastal plain of Suriname. Geol. Mijnb./Neth. J. Geosci. 1979, 58, 21-28.

47. Groen, K. The Effects of Transgressions and Regressions on Coastal and Offshore Groundwaters. A Case Study of Suriname and Generic Studies into Groundwater Flow Systems, Salinity Patterns, and Paleo Groundwater. Ph.D. Thesis, Vrije Universiteit, Amsterdam, The Netherlands, 8 October 2002; p. 192.

48. Balsem, T.; Rhebergen, G.J. Bodemgesteldheid en geomorfologie langs de Midden-Suriname en de Midden-Saramacca Rivier; Report Dienst Bodemkartering; Unpublished Report; Dienst Bodemkartering: Paramaribo, Suriname, 1979.

49. Kips, P.H.A.; Snel, A.R. Landschap, bodemgesteldheid en landgeschiktheid langs de Midden-Suriname Rivier (Goejaba-Botopassi); Unpublished Report; Dienst Bodemkartering: Paramaribo, Suriname, 1979; p. 229.

50. D'Audretsch, F.C. Geological Map 1:100.000 D7, Sheet Kabel; Geological Mining Services Suriname, 1 Map: Paramaribo, Suriname, 1957; p. 58.

51. Martin, K. Aantekeningen bij een geognostische overzichtskaart van Suriname. Tijdschr. Kon. Ned. Aardrk. Gen. 1888, 5, 444-453.

52. Bleys, C. Over steenbanken bij het Brokopondoeiland (Suriname). Geol. Mijnb./Neth. J. Geosci. 1953, 15, $194-202$.

53. Peulvast, J.-P.; Sales, V.C.; Bétard, F.; Gunnell, Y. Low post-Cenomanian denudation depths across the Brazilian Northeast: Implications for long-term landscape evolution at a transform continental margin. Glob. Planet. Chang. 2008, 62, 39-60. [CrossRef]

54. Girjasing, R.; Kroonenberg, S.B.; Ramdajal, R.; Wong, T.H. Timing of the origin and uplift of the Bakhuis-Tambaredjo Horst, Suriname. In Proceedings of the 11th International Guiana Geological Conference, Paramaribo, Suriname, 19-20 February 2019; pp. 67-70. 
55. Beunk, F.F.; de Roever, E.W.; Yi, K.; Brouwer, F.M. Structural and tectonothermal evolution of the ultrahigh-temperature Bakhuis Granulite Belt, Guiana Shield, Surinam: Palaeoproterozoic to recent. Geosci. Front. 2021, 12, 677-692. [CrossRef]

56. Bauer, B.O.; Bull, W.B. Geomorphic responses to climatic change. Geogr. Rev. 1993, 83, 114. [CrossRef]

57. Vandenberghe, J. River terraces as a response to climatic forcing: Formation processes, sedimentary characteristics and sites for human occupation. Quat. Int. 2015, 370,3-11. [CrossRef]

58. Veldkamp, A.; Vandenberg, M.; Veldkamp, T. Three-dimensional modelling of Quaternary fluvial dynamics in a climo-tectonic dependent system. A case study of the Maas record (Maastricht, The Netherlands). Glob. Planet. Chang. 1993, 8, 203-218. [CrossRef]

59. Haq, B.U.; Hardenbol, J.; Vail, P.R. Chronology of fluctuating sea levels since the triassic. Science 1987, 235, 1156-1167. [CrossRef]

60. Van Balen, R.; Van Der Beek, P.; Cloetingh, S. The effect of rift shoulder erosion on stratal patterns at passive margins: Implications for sequence stratigraphy. Earth Planet. Sci. Lett. 1995, 134, 527-544. [CrossRef]

61. Viveen, W.; Schoorl, J.; Veldkamp, A.; Van Balen, R.; Desprat, S.; Vidal-Romani, J. Reconstructing the interacting effects of base level, climate, and tectonic uplift in the lower Mino River terrace record: A gradient modelling evaluation. Geomorphology 2013, 186, 96-118. [CrossRef]

62. Brinkman, R.; Pons, L.; Brinkman, R.; Pons, L. A pedo-geomorphological classification and map of the holocene sediments in the coastal plain of the three guianas. In Soil Survey Papers; Soil Survey Institute: Wageningen, The Netherlands, 1968 ; Volume 4.

63. Veen, A.W.L. On Geogenesis and Pedogenesis in the Old Coastal Plain of Suriname (South America); Dienst Bodemkartering Suriname: Amsterdam, The Netherlands, 1970; p. 176.

64. Wong, T. Outline of the stratigraphy and the geological history of the Suriname coastal plain. Geol. Mijnb./Neth. J. Geosci. 1986, 65, 223-241.

65. Brinkman, R. Bodemkartering Albina Zuid; Unpublished Report; Dienst Bodemkartering: Marowijne, Suriname, 1959. 